\title{
EVALUASI PERAN KOMITE PENJAMIN MUTU (KPM) DALAM MANAJEMEN KUALITAS MUTU PENYELENGGARAAN DIKLAT PRAJABATAN DAN KEPEMIMPINAN
}

\section{EVALUATION OF THE ROLE OF QUALITY ASSURANCE COMMITTEE IN PRE SERVICE AND LEADERSHIP TRAINING QUALITY ASSURANCE MANAGEMENT}

\author{
Siti Tunsiah, S.IP \\ Lembaga Administrasi Negara
}

\begin{abstract}
Abstrak
Diklat merupakan salah satu upaya pengembangan kompetensi yang dilakukan untuk mengisi kesenjangan kompetensi yang dimiliki Aparatur Sipil Negara (ASN) dalam melaksanakan tugas dan fungsi jabatannya. Untuk itu penyelenggaraan Diklat mulai dari perencanaan sampai dengan evaluasi harus dipastikan sesuai dengan pedoman penyelenggaraan baik secara substantif maupun administratif, dengan harapan tujuan penyelenggaraan Diklat untuk memenuhi kesenjangan kompetensi dapat tercapai. Peran Komite Penjamin Mutu (KPM) merupakan salah satu unsur yang dapat dimanfaatkan dalam mengawal penyelenggaraan Diklat sesuai dengan tugas dan fungsinya sebagai KPM. Berdasarkan hasil monitoring dan evaluasi yang dilakukan oleh Pusat Pengembangan Program dan Pembinaan LAN terhadap beberapa Lembaga Diklat, diperoleh data bahwa peran KPM belum dilakukan secara maksimal, KPM hanya sebatas diikutkan pada kegiatan rapat-rapat penyelenggaraan saja, belum kepada pelibatan pembuatan standar mutu baku penyelenggaraan Diklat yang dapat berupa petunjuk teknis penyelenggaraan ataupun Standar Operating Prosedur (SOP) kegiatan penyelenggaraan Diklat, pembuatan instrumen evaluasi penyelenggaraan atau bahkan evaluasi pasca pelatihan. Untuk itu, peran KPM harus dapat dimaksimalkan kembali, terutama pada saat melakukan monitoring dan evaluasi pasca Diklat sehingga Lembaga Diklat memiliki dan menyajikan data kualitas lulusan Diklat untuk membantu meningkatkan hasil diklat.
\end{abstract}

Kata Kunci: diklat, Komite Penjamin Mutu, kualitas diklat

\begin{abstract}
Training is one of competence development efforts to fill competency gap of State Civil Apparatus(ASN) in performing duties and function of particular position. To achieve training objective, training management, starting from planning to evaluation, must be in accordance with the implementation guidelines. Quality Assurance Committee (KPM) is one of the elements that can be utilized to oversee training implementation. Based on the results of monitoring and evaluation conducted by the Center for Training Program Development and Fostering, KPMs in some training centers have not performed well. KPMs were not involved in developing quality standards, such as through developing training evaluation instruments and post training evaluation. therefore, KPMs should improve their role as training quality assurance, particularly in conducting post-training monitoring and evaluation in order to obtain data on the quality of training graduates to help the institution meet the training objective.
\end{abstract}

Keywords : training, Quality Assurance Committee, training quality 


\section{A. Pendahuluan}

Diklat Aparatur Sipil Negara
(ASN) merupakan proses belajar mengajar dalam rangka meningkatkan kompetensi pegawai ASN. Sebagai suatu proses belajar mengajar diharapkan ASN yang telah mengikuti Diklat dapat meningkatkan pengetahuan (knowledge), keterampilan (skills) ataupun sikap perilaku (attitude) atau biasa disingkat dengan akronim KSA. Dengan adanya penambahan nilai (value added) baik pengetahuan, keterampilan maupun, sikap perilaku dari sebuah Diklat diharapkan ASN dapat meningkatkan kompetensinya dan bekerja sesuai dengan tugas dan fungsinya masing-masing sehingga apa yang menjadi tujuan organisasi dapat tercapai. Kompetensi sebagaimana terdapat dalam pasal 69 ayat (3) UndangUndang ASN terdiri dari:

1. kompetensi teknis yang diukur dari tingkat dan spesialisasi pendidikan, pelatihan teknis fungsional, dan pengalaman bekerja secara teknis;

2. kompetensi manajerial yang diukur dari tingkat pendidikan, pelatihan struktural atau manajemen, dan pengalaman kepemimpinan; dan

3. kompetensi sosial kultural yang diukur dari pengalaman kerja berkaitan dengan masyarakat majemuk dalam hal agama, suku, dan budaya sehingga memiliki wawasan kebangsaan.

Penambahan nilai (value added) dalam suatu pelatihan ASN dipengaruhi oleh berbagai unsur yang menjadikan penambahan nilai tersebut benar-benar sesuai dengan kualitas yang diharapkan. Unsur yang mempengaruhi merupakan unsur pembentuk dan unsur penunjang dari terselenggaranya pelatihan tersebut yang terdiri dari:

\section{Peserta Pelatihan}

Peserta pelatihan mempunyai peran tersendiri dalam mensukseskan penyelenggaraan Diklat karena peserta memiliki kemampuan dan keinginan awal yang berbeda-beda sehingga keberhasilan Diklat tergantung kemampuan peserta masingmasing. Kemampuan dan keinginan peserta selama berlangsung Diklat akan menentukan kualitas Diklat itu sendiri. Agar kemampuan peserta itu memiliki tingkat kemampuan yang rata-rata sama, maka itu dalam Diklat ASN biasanya terdapat aturan tersendiri mengenai syarat yang harus dimiliki bagi seorang peserta untuk mengikuti Diklat tertentu, misalnya syarat peserta untuk mengikuti Diklat Kepemimpinan dilihat dari Pangkat/Golongan Pegawai yang bersangkutan, pernah mengikuti Diklat pada jenjang sebelumnya, dan lain-lain.

\section{Bahan Ajar yang digunakan}

Bahan ajar merupakan salah satu unsur yang harus ada dalam suatu pelatihan. Modul merupakan bahan ajar minimal yang harus ada dalam suatu pelatihan, dapat pula dilengkapi dengan studi kasus, dan film pendek. Bahan ajar dapat berupa hard atau soft copy yang pada prinsipnya dapat dibaca oleh peserta serta memudahkan bagi penyelenggara Diklat untuk mengadakan bahan ajar tersebut.

\section{Tenaga pengajar}

Pemilihan tenaga pengajar merupakan salah satu unsur yang sangat menentukan dalam kualitas lulusan Diklat. Tenaga pengajar yang akan mengajar sebelumnya akan diikutkan pula pada pelatihan khusus untuk tenaga pengajar sehingga yang bersangkutan memiliki kompetensi untuk mentransfer pengetahuan yang dimilikinya dengan metode pengajaran yang dapat dipertanggungjawabkan. Selain widyaiswara, saat ini, tenaga pengajar dapat berasal dari non widyaiswara yang diberikan kesempatan untuk mengajar dengan syarat telah mengikuti pelatihan untuk mengajar, yang disebut dengan 
Training of Trainner (TOT). Selain itu juga tenaga pengajar dapat berasal yang ahli/ pakar di bidangnya.

Penilaian tenaga pengajar dapat dilakukan dengan menilai beberapa kriteria seperti metode pembelajaran yang digunakan, cara menyampaikan materi, kedisiplinan masuk kelas, sikap dan perilaku yang ditunjukan selama di dalam kelas.

\section{Sarana dan Prasarana}

Merupakan suatu keniscayaan dalam suatu penyelenggaraan Diklat adalah dimilikinya sarana dan prasarana yang memadai agar pelaksanaan Diklat berjalan dengan lancar. Sarana dan prasarana yang dimiliki harus menunjang kepada tujuan pembelajaran, misalnya adanya ruang kelas, aula, ruang kelas kecil, perpustakaan, sarana olahraga, ruang makan, ruang administrasi, dan lain sebagainya. Sarana dan prasarana tersebut sebaiknya dimiliki oleh Lembaga Penyelenggara Pelatihan, dalam hal ini sarana yang dimiliki bukan menyewa. Untuk sarana dan prasarana minimal sudah digambarkan dalam pedoman penyelenggaraan Diklat masing-masing, baik Diklat Prajabatan, Diklat Kepemimpinan, maupun Diklat Teknis dan Fungsional.

\section{Layanan petugas/ penyelenggara}

Pemberian layanan petugas/ penyelenggara Diklat dapat berdampak kepada keberlangsungan penyelenggaraan pelatihan dan kualitas penyelenggaraannya. Pemberian pelayanan minimal harus diberikan kepada peserta sehingga apa yang dibutuhkan peserta dapat direspon dengan baik. Selama penyelenggaraan pelatihan biasanya tersedia petugas piket yang akan melayani kebutuhan peserta misalnya untuk kepentingan mencetak bahan belajar, penyediaan alat tulis selama pembelajaran berlangsung, penyediaan obat-obatan jika peserta ada yang sakit.

Kesemua unsur di atas dalam penyelenggaraan Diklat pada prosesnya dapat dipantau oleh Komite Penjamin Mutu (KPM). KPM sebagai tim yang harus memastikan kualitas penyelenggaraan Diklat mempunyai peran yang sangat strategis dalam pengendalian kepatuhan penyelenggara Diklat menjalankan tugasnya. Peran dan fungsi KPM juga telah diatur dalam peraturan yang mengatur tentang akreditasi lembaga pelatihan. Dikeluarkannya Peraturan Kepala Lembaga Administrasi Negara (Perka LAN) Nomor 16, 17, dan 18 tahun 2013 tentang Pedoman Akreditasi Lembaga Pendidikan dan Pelatihan Pemerintah Penyelenggara Pendidikan dan Pelatihan Prajabatan dan Kepemimpinan, Fungsional dan Teknis kemudian direvisi dengan Peraturan Kepala LAN Nomor 25 tahun 2015 tentang Pedoman Akreditasi Lembaga Pendidikan dan Pelatihan Pemerintah, menyebutkan peran Komite Penjamin Mutu (KPM) menjadi salah satu sub unsur penilaian yang sangat penting. Dalam Perka tersebut KPM memiliki fungsi yang sangat penting sebagai penjamin mutu yang merupakan salah satu unsur dalam akreditasi dan masuk ke dalam sub unsur Organisasi Lembaga Diklat.

Permasalahan dalam tulisan ini adalah apakah KPM yang dimiliki oleh beberapa Lembaga Diklat sudah menjalankan tugas dan fungsinya sesuai dengan yang telah diamanatkan? KPM yang memiliki peran dalam peningkatan kualitas penyelenggaraan Diklat perannya masih belum dirasakan signifikan pada berbagai lembaga Diklat, misalnya pada beberapa Lembaga Diklat KPM hanya dibentuk sekedar memenuhi persyaratan akreditasi saja. KPM 
merupakan tim independen yang dibentuk oleh Lembaga Diklat guna dapat melakukan perpanjangan tangan menjalankan delegasi dari Lembaga Administrasi Negara (LAN) dalam memantau dan mengevaluasi penyelenggaraan Diklat belum dirasakan manfaatnya dan memberikan umpan balik baik kepada instansi penyelenggara Diklat maupun kepada LAN. Untuk itu maka diperlukan evaluasi kembali terkait peran KPM dalam manajemen kualitas mutu penyelenggaraan Diklat Prajabatan dan Kepemimpinan.

Adapun tujuan dari penulisan ini adalah untuk mengevaluasi peran KPM dalam manajemen kualitas mutu penyelenggaraan Diklat pada Lembaga Diklat yang telah dilakukan monitoring dan evaluasi penyelenggaraan Diklat Prajabatan dan Kepemimpinan oleh Pusat Pengembangan Program dan Pembinaan Diklat, LAN.

\section{B. Kerangka Teori}

Konsep yang digunakan sebagai pijakan dalam melakukan analisa peran Komite Penjamin Mutu dalam Kualitas Penyelenggaraan Diklat yaitu:

\section{Evaluasi}

Evaluasi merupakan bagian dari sistem manajemen yaitu perencanaan, organisasi, pelaksanaan, monitoring, dan evaluasi. Pemahaman mengenai pengertian evaluasi dapat berbedabeda sesuai dengan pengertian evaluasi yang bervariatif oleh para pakar evaluasi. Menurut Djaali dan Pudji (2008: 01) evaluasi diartikan sebagai proses menilai sesuatu berdasarkan kriteria atau tujuan yang telah ditetapkan yang selanjutnya diikuti oleh pengambilan keputusan atas obyek yang difasilitasi. Sedangkan Ahmad (2007:133) mengatakan bahwa "evaluasi diartikan sebagai proses sistema- tis untuk menentukan nilai sesuatu (ketentuan, kegiatan, unjuk kerja, proses, orang, obyek, dan lain-lain) bersadarkan kriteria tertentu melalui penilaian.

\section{Kualitas Mutu}

Philip B. Crosby (1979) mendefinisikan mutu sebagai kesesuaian dengan apa yang disyaratkan atau distandarkan (conformance to requirement). Cara untuk mencapai mutu dari produk atau jasa menurut Crosby (1979) ada 14 langkah, meliputi:

a. Komitmen pada pimpinan. Inisiatif pencapaian mutu pada umumnya oleh pimpinan dan dikomunikasikan sebagai kebijakan secara jelas dan dimengerti oleh seluruh unsur pelaksana lembaga.

b. Bentuk tim perbaikan mutu yang bertugas merumuskan dan mengendalikan program peningkatan mutu.

c. Buatlah pengukuran mutu, dengan cara tentukan baseline data saat program peningkatan mutu dimulai, dan tentukan standar mutu yang diinginkan sebagai patokan. Dalam penetuan standar mutu libatkan pelanggan agar dapat diketahui harapan dan kebutuhan mereka.

d. Menghitung biaya mutu. Setiap mutu dari suatu produk/jasa dihitung termasuk di dalamnya antara lain: jika terjadi pengulangan pekerjaan jika terjadi kesalahan, inspeksi/ supervisi, dan percobaan.

e. Membangkitkan kesadaran akan mutu bagi setiap orang yang terlibat dalam proses produksi/ jasa dalam lembaga.

f. Melakukan tindakan perbaikan. Untuk itu perlu metode yang sistematis agar tindakan yang dilakukannya cocok dengan penyelesaian masalah yang 
dihadapi, dan karenanya perlu dibuat suatu seri tugas-tugas tim dalam agenda yang cermat. Selama pelaksanaan keputusan, sebaiknya dilakukan pertemuan reguler agar didapat feedback dari mereka.

g. Lakukan perencanaan kerja tanpa cacat (zero defect planning) dari pimpinan sampai pada seluruh staf pelaksana.

h. Adakan pelatihan pada tingkat pimpinan (supervisor training) untuk mengetahui peranan mereka masing-masing dalam proses pencapaian mutu, teristimewa bagi pimpinan tingkat menengah. Lebih lanjut juga bagi pimpinan tingkat bawah dan pelaksanaannya.

i. Adakan hari tanpa cacat, untuk menciptakan komitmen dan kesadaran tentang pentingnya pengembangan staf.

j. Goal setting. Setiap tim/ bagian merumuskan tujuan yang akan dicapai dengan tepat dan harus dapat diukur keberhasilannya.

k. Berusaha menghilangkan penyebab kesalahan. Ini berarti sekaligus melakukan usaha perbaikan. Salah satu dari usaha ini adalah adanya kesempatan staf mengkomunikasikan pekerjaannya yang sulit dilakukan.

1. Harus ada pengakuan atas prestasi bukan berupa uang tapi misalnya penghargaan atau serftifikat dan lainnya sejenis.

m. Bentuk suatu Komisi Mutu, yang secara profesional akan merencanakan usaha-usaha perbaikan mutu dan moneter secara berkelanjuan.

n. Lakukan berulangkali, karena program mencapai mutu penuh akan berakhir.

Mengacu kepada teori Philip B. Crosby, maka peran KPM dalam kualitas penyelenggaraan Diklat memiliki peran yang sangat penting karena KPM merupakan tim perbaikan mutu yang bertugas merumuskan dan mengendalikan program peningkatan mutu.

Walaupun tim perbaikan mutu bukan satu-satunya langkah dalam pencapaian mutu, namun secara peran dan fungsi dapat menggerakkan langkah lainnya karena KPM merupakan tim independen yang ditunjuk untuk menjamin kualitas penyelenggaraan Diklat.

\section{Metode Penelitian}

Metode yang digunakan untuk menggali informasi dalam analisis ini adalah metode deskriptif analitis, yaitu suatu metode yang berfungsi untuk mendeskripsikan atau memberi gambaran terhadap objek yang diteliti melalui data atau sampel yang telah terkumpul sebagaimana adanya tanpa melakukan analisis dan membuat kesimpulan yang berlaku untuk umum (Sugiyono, 2009: 29).

Metode yang digunakan dalam pencarian data dan informasi yaitu studi literatur terhadap peraturan perundangundangan dan hasil monitoring dan evaluasi penyelenggaraan Diklat, baik Pelatihan Kepemimpinan, Prajabatan maupun Teknis Fungsional.

1. Metode yuridis normatif

Metode ini dilakukan melalui studi pustaka, menelaah data sekunder berupa Peraturan Perundang-undangan yang terkait yaitu:

a. Undang-Undang Nomor 5 tahun 2015 tentang Aparatur Sipil Negara

b. Peraturan Pemerintah Nomor 11 tahun 2017 tentang Manajemen Pegawai Negeri Sipil

c. Peraturan Kepala LAN Nomor 14 tahun 2013 tentang SOTK LAN

d. Peraturan Kepala LAN Nomor 25 tahun 2015 tentang Pedoman Akreditasi Lembaga Diklat. 
e. Peraturan Kepala LAN Nomor 21 tahun 2016 tentang Pedoman Penyelenggaraan Pelatihan Dasar Calon Pegawai Negeri Sipil Golongan III.

f. Peraturan Kepala LAN Nomor 22 tahun 2016 tentang Pedoman Penyelenggaraan Pelatihan Dasar Calon Pegawai Negeri Sipil Golongan I dan Golongan II.

\section{Studi Literatur/Kepustakaan}

Studi litelatur dilakukan dengan mempelajari dan menelaah referensi yang sesuai baik melalui buku, jurnal, artikel ataupun laporan yang berkaitan dengan peran Komite Penjamin Mutu pelatihan dan manajemen kualitas mutu.

3. Hasil Laporan Monitoring dan Evaluasi Penyelenggaraan Pelatihan Lembaga Administrasi Negara c.q. Pusat Pengembangan Program dan Pembinaan Diklat salah satu fungsinya yaitu melakukan monitoring dan evaluasi penyelenggaraan Diklat. Dalam pelaksanaannya karena terbatasnya anggaran yang dimiliki, monitoring dan evaluasi hanya dilakukan terhadap beberapa lokus terpilih saja yaitu terhadap Lembaga Pelatihan yang memang telah terakreditasi program Diklatnya. Laporan hasil monitoring dan evaluasi penyelenggaraan Diklat pada tahun 2017 dijadikan dasar penulis dalam menyajikan data dan informasi terkait dengan peran KPM.

\section{Hasil Dan Pembahasan}

Penjaminan mutu sebagaimana tertuang dalam Peraturan Kepala LAN Nomor 25 tahun 2015 merupakan proses penjaminan penerapan standar penyelenggaraan Diklat sesuai dengan peraturan yang berlaku. Penjaminan mutu dilakukan oleh Komite Penjamin Mutu dengan mendapatkan prosentase $10 \%$ (sepuluh persen) dari total keseluruhan sub unsur yang dinilai dalam proses pengakreditasian Lembaga Pelatihan, dengan pembagian skor sebagai berikut:

1. Ada standar mutu yang menjadi acuan lembaga diklat yang diimplementasikan dalam bentuk berbagai pedoman dan dijamin oleh tim penjamin mutu yang independen, skor $=4$ (Sangat baik);

2. Ada standar mutu yang menjadi acuan lembaga diklat yang diimplementasikan dalam bentuk berbagai pedoman namun penjaminan dilakukan oleh tim penjamin mutu internal, skor $=3$ (baik);

3. Ada standar mutu yang menjadi acuan lembaga diklat tetapi kurang diimplementasikan dalam bentuk berbagai pedoman meskipun dijamin oleh tim penjamin mutu yang independen, skor = 2 (cukup);

4. Ada standar mutu yang menjadi acuan lembaga diklat tetapi kurang diimplementasikan dalam bentuk berbagai pedoman meskipun dijamin oleh tim penjamin mutu internal, skor $=1$ (kurang);

5. Tidak ada standar mutu atau tidak dilakukan penjaminan mutu, skor $=0$ (sangat kurang).

Berdasarkan uraian diatas, skor penjaminan mutu ditunjukan dengan adanya standar mutu yang dimliki oleh instansi penyelenggara Diklat dan digunakan dalam penyelenggaraan Diklat, misalnya adanya petunjuk teknis penyelenggaraan Diklat ataupun adanya Standar Operating Prosedur (SOP) terkait dengan penyelenggaraan Diklat. Standar mutu tertinggi yang digunakan sebagai acuan lembaga Diklat dalam penyelenggaraan Diklat Kepemimpinan dan Diklat Prajabatan/ Pelatihan Dasar CPNS tentunya Peraturan Kepala LAN tentang penyelenggaraan Diklat tersebut. Selanjutnya, instansi penyelenggara dapat membuat aturan turunan berupa panduan penyelenggaraan yang merupakan pengejawantahan teknis dari 
Peraturan Kepala LAN sehingga penyelenggaraan Diklat sesuai dengan standar yang telah ditetapkan.

KPM sebagai tim independen dapat membantu penyelenggara pelatihan dengan membuat draft usulan pedoman standar mutu yang kemudian dimintakan persetujuannya dengan Pimpinan instansi penyelenggara Diklat. Standar mutu yan digunakan harus dapat memotret penyelenggaraan Diklat mulai dari perencanaan sampai dengan evaluasi.

Lebih lanjut, langkah yang disebutkan oleh Crosby (1979) sebagaimana disebutkan dalam teorinya dapat diimplementasikan oleh instansi Diklat mulai dari komitmen yang dimiliki pimpinan untuk memiliki misi selalu mengedepankan kualitas mutu, menginformasikannya sampai dengan level staf, membuat instrumen pengukuran kualitas, sampai dengan membentuk tim khusus yang memantau kualitas mutu penyelenggaraan. Bagi Lembaga Diklat yang telah mendapatkan akreditasi dari LAN, penjaminan mutu dilakukan oleh KPM.

Berdasarkan data yang diperoleh melalui Kepala Subbidang Akreditasi LAN, Lembaga Diklat terkareditasi telah memiliki KPM, baik yang pembentukannya masih baru atau yang sudah lama. Fungsi dan keanggotaan KPM telah diatur juga dalam Peraturan Kepala LAN nomor 25 tahun 2017 tersebut. Pasal 13 ayat (1) Sub unsur Penjaminan Mutu adalah proses penjaminan penerapan standar penyelenggaraan Diklat sesuai dengan ketentuan yang telah ditetapkan, ayat (2) Sub unsur Komite Penjaminan Mutu Lembaga Diklat yang bertanggungjawab dalam menjamin kualitas penyelenggaraan Diklat, ayat (2) Anggota Komite Penjamin Mutu terdiri dari ASN dan Praktisi yang memiliki kemampuan melaksanakan penjaminan mutu Lembaga Diklat, ayat (4) Jumlah anggota KPM paling sedikit 3 orang dan paling banyak 5 orang.
Standar keterlibatan KPM dapat dilibatkan sejak awal rapat persiapan penyelenggaraan pelatihan. Pada saat rapat persiapan dapat dilakukan pengecekan terhadap beberapa hal sebagai berikut:

1. Daftar checklist persiapan;

2. Master jadwal dan jadwal mingguan;

3. Program kegiatan peserta selama diasramakan;

4. Daftar nominatif calon peserta Diklat;

5. Daftar nominatif calon pengajar dan penceramah;

6. Daftar nominatif calon panitia penyelenggara;

7. Kelengkapan peserta Diklat;

8. Tempat dan lokasi penyelenggaraan;

9. Dukungan sarana dan prasarana Diklat;

10. Dukungan sarana dan prasarana pembelajaran;

11. Kesesuaian komponen pembiayaan;

12. Dukungan Administrasi (surat menyurat, formulir-formulir, pemberian KRA, dan verifikasi STTPP); dan

13. Hal-hal teknis lainnya

Pada tahap pelaksaan, KPM dapat melakukan pengecekan terhadap hal-hal :

1. Menghadiri acara pembukaan Diklat;

2. Memberikan ceramah dan/atau overview kebijakan penyelenggaraan Diklat;

3. Monitoring dan evaluasi (monev) penyelenggaraan;

4. Memberikan penjelasan penyamaan persepsi penguji, coach, dan mentor;

5. Penjadwalan pengawas ujian;

6. Penjadwalan penguji seminar;

7. Penjadwalan evaluasi akhir (kelulusan);

8. Memberikan review kebijakan penyelenggaraan Diklat;

9. Menghadiri penutupan Diklat.

Pada tahap evaluasi KPM dapat melakukan:

1. pelaksanaan evaluasi akhir (evaluasi kelulusan peserta) secara transparan dan obyektif; 
2. mekanisme dan prosedur penerbitan KRA dilakukan sesuai prosedur dengan memenuhi persyaratan administratif dan substantif yang diperlukan;

3. format penulisan STTPP sesuai dengan ketentuan.

Deskripsi indikator penilaian penjaminan mutu:

1. Adanya standar mutu (SOP \& instruksi kerja)

2. Implementasi standar mutu berbagai pedoman dalam penyelenggaraan Diklat

3. Komite Penjamin Mutu Independen

Kewenangan yang dapat dilakukan oleh KPM sebagaimana disebutkan di atas yaitu mulai dari perencanaan sampai dengan evaluasi, maka KPM dapat diartikan sebagai polisi lalu lintas yang mengatur jalannya penyelenggaraan pelatihan sehingga penyimpangan dalam seluruh rangkaian penyelenggaraan Diklat mulai dari perencanaam pelaksanaan, sampai dengan evaluasinya. KPM merupakan perpanjangan tangan dari LAN, bertugas menjaga kualitas penyelenggaraan Diklat sehingga dalam penyelenggaraan Diklat sesuai dengan aturan yang telah diterbitkan.

Berdasarkan data yang diperoleh dari Sub Bidang Akreditasi LAN, jumlah Lembaga Diklat yang telah diakreditasi dapat digambarkan sebagai berikut:

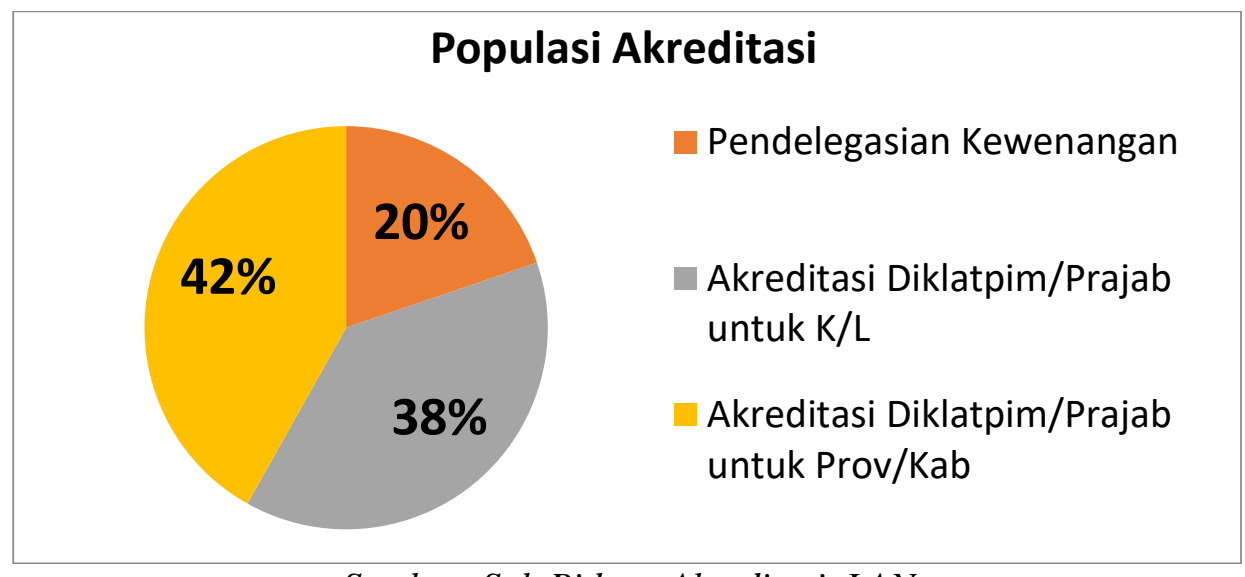

Sumber: Sub Bidang Akreditasi, LAN

Dari sebaran Lembaga Diklat yang telah diakreditasi menunjukan bahwa Program Pelatihan Kepemimpinan dan Prajabatan pada pemerintah Daerah, baik provinsi dan sebagian Kab/Kota memiliki jumlah yang paling banyak yaitu sebesar $42 \%$ (empat puluh dua persen). Hal ini disebabkan karena jumlah instansi Daerah cukup banyak, yaitu ada 33 (tiga puluh tiga) provinsi dan 510 (lima ratus sepuluh) kabupaten dan kota. Dari data tersebut memang belum semua Provinsi program pelatihan Kepemimpinan dan Prajabatannya sudah mengajukan untuk diakreditasi.

Dari jumlah $42 \%$ tersebut pada tahun 2017 telah dilakukan monitoring terhadap 8 (delapan) Lembaga Diklat, baik program
Diklat Kepemimpinan maupun Prajabatan, yaitu:

1. Badan Pengembangan Sumber Daya Manusia (BPSDM) Provinsi Lampung;

2. Badan Pengembangan Sumber Daya Manusia (BPSDM) Provinsi Kalimantan Timur;

3. Badan Pengembangan Sumber Daya Manusia (BPSDM) Nusa Tenggara Timur;

4. Badan Pengembangan Sumber Daya Manusia (BPSDM) Gorontalo;

5. Badan Pengembangan Sumber Daya Manusia (BPSDM) Sragen;

6. Pusat Kajian dan Pendidikan dan Pelatihan Aparatur I LAN Jatinangor; 
7. Badan Pengembangan Sumber Daya Manusia (BPSDM) Provinsi Riau;

8. Badan Pengembangan Sumber Daya Manusia (BPSDM) Sulawesi Selatan.

Monitoring dan evaluasi dilakukan dengan menggunakan elektronik monitoring dan evaluasi (e-monev) terhadap peserta dalam bentuk pengisian kuesioner, sedangkan instrumen terhadap pengelola, penyelenggara, dan KPM menggunakan instrumen manual. Instrumen terhadap KPM dilakukan dengan metode wawancara dan secara garis besar hasilnya dapat digambarkan sebagai berikut:

\section{Ketersediaan SK pengangkatan menjadi KPM}

KPM merupakan syarat mutlak yang harus dimiliki oleh semua Lembaga Diklat jika ingin mengajukan akreditasi program Diklatnya. Bukti Lembaga Diklat memiliki KPM dibuktikan dengan adanya surat keterangan, surat pengangkatan, atau surat tugas bagi semua anggota KPM. Untuk itu kedelapan Lembaga Diklat tersebut sudah memiliki SK pengangkatan KPM di masing-masing instansinya. SK KPM terdiri dari paling sedikit 3 (tiga) orang dan paling banyak 5 (lima) orang dengan melibatkan anggota di luar instansi penyelenggara. Hal ini dapat berasal dari akademisi atau profesional yang memahami penyelenggaraan Diklat.

KPM adalah syarat wajib pengajuan akreditasi yang harus dimiliki oleh Instansi penyelenggara, maka semua Instansi penyelenggara yang tekah diakreditasi telah memiliki tim KPM. Tim yang telah ditunjuk sebagaimana yang telah diuraikan diatas lebih kurang adalah sebagai polisi lalu lintas yang mengatur jalannya penyelenggaraan Diklat, bahkan seharusnya sampai dengan evaluasi pasca Diklat.
2. Tindak Lanjut yang sudah dilakukan oleh KPM pasca perolehan Akreditasi

Untuk tindak lanjut yang telah dilakukan oleh KPM, sebagian besar hanya diikutkan pada rapat penyelenggaraan Diklat saja, yaitu mulai dari rapat persiapan sampai dengan rapat kelulusan.

Kebermanfaatan KPM dalam mengevaluasi peserta Pelatihan belum nampak terlihat, ini dibuktikan pada hasil wawancara yang dilakukan oleh tim, diperoleh keterangan bahwa kedelapan Lembaga Diklat diatas belum merumuskan instrumen evaluasi penyelenggaraan secara khusus memang dibuat oleh KPM. Lebih jauh KPM belum membuat instrumen evaluasi pasca Diklat yang dapat memotret kebermanfaatan lulusan peserta Diklat dalam jabatannya. Dari 8 (delapan) lembaga Diklat yang menjadi lokus monitoring dan evaluasi pasca Diklat dapat dikatakan bahwa peran KPM belum sesuai dengan tugas dan fungsi yang sesungguhnya.

\section{Ketersediaan pedoman yang digunakan, misalnya juknis atau Standard Operating Procedur (SOP)}

Juknis dan SOP merupakan standar penyelenggaraan Pedoman yang lebih rinci dijadikan acuan Lembaga Diklat dalam menyelenggarakan Diklat. Dari kedelapan Lembaga Diklat yang telah dilakukan monitoring evaluasi diperoleh data bahwa belum semua Lembaga Diklat memiliki Petunjuk Teknis dan SOP. Hal ini dipertegas dengan pernyataan salah satu Bidang pada BPSDM Lampung yang mengatakan bahwa Peraturan Kepala LAN tentang penyelenggaraan Diklat Kepemimpinan dan Prjabatan dinilai sudah cukup, sehingga tidak perlu dibuatkan aturan turunannya. 


\section{Ketersediaan instrumen pengukuran monev pasca Diklat yang dilakukan oleh KPM}

Monitoring dan evaluasi dalam suatu penyelenggaraan Diklat wajib dilakukan, hal ini dengan tujuan agar Lembaga Diklat mengetahui kekurangan dan kelebihan dalam penyelenggaraan pelatihan tersebut. Kekurangan yang terjadi dapat dijadikan bahan perbaikan untuk penyelenggaraan selanjutnya. Monitoring terdiri dari on going monitoring, yaitu pada saat Diklat masih berlangsung, monitoring penyelenggaraan yaitu yang dilakukan pada saat Diklat telah berakhir, dan monitoring pasca Diklat yaitu dapat dilakukan minimal 6 (enam) bulan setelah penyelenggaraan Diklat selesai. Monitoring pasca Diklat masih jarang dilakukan oleh Instansi Penyelenggara Diklat, padahal sesuai dengan Pedoman Penyelenggaraan Diklat bahwa monitoring dan evaluasi pasca Diklat menjadi kewajiban Instansi Penyelenggara Diklat untuk menyelenggarakan. Hal ini sebenarnya memiliki dampak yang sangat besar jika memang dilakukan yaitu untuk melihat kebermanfaatan lulusan Diklat dalam mengerjakan tugas dan fungsinya, sehingga dapat tergambarkan perbedaan sebelum dan sesudah mengikuti Diklat.

Tabel 1. Cheklist Unsur Penilaian KPM

\begin{tabular}{|c|c|c|c|c|c|}
\hline \multirow[b]{2}{*}{ NO } & \multirow[b]{2}{*}{ Lokus Monitoring Evaluasi } & \multicolumn{4}{|c|}{ Unsur yang ditanyakan } \\
\hline & & $\begin{array}{l}\text { Ketersediaan SK } \\
\text { pengangkatan } \\
\text { KPM }\end{array}$ & $\begin{array}{l}\text { Tindak Lanjut } \\
\text { KPM }\end{array}$ & $\begin{array}{l}\text { Ketersediaan } \\
\text { Pedoman } \\
\text { Penyelenggaraan }\end{array}$ & $\begin{array}{l}\text { Ketersediaan } \\
\text { Instrumen } \\
\text { Evaluasi }\end{array}$ \\
\hline 1. & $\begin{array}{l}\text { Badan Pengembangan Sumber Daya } \\
\text { Manusia } \\
\text { Lampung }\end{array}$ & $\sqrt{ }$ & - & - & - \\
\hline 2. & $\begin{array}{l}\text { Badan Pengembangan Sumber Daya } \\
\text { Manusia (BPSDM) Provinsi } \\
\text { Kalimantan Timur }\end{array}$ & $\sqrt{ }$ & - & - & - \\
\hline 3. & $\begin{array}{l}\text { Badan Pengembangan Sumber Daya } \\
\text { Manusia (BPSDM) Nusa Tenggara } \\
\text { Timur }\end{array}$ & $\sqrt{ }$ & - & - & - \\
\hline 4. & $\begin{array}{l}\text { Badan Pengembangan Sumber Daya } \\
\text { Manusia (BPSDM) Gorontalo }\end{array}$ & $\sqrt{ }$ & - & - & - \\
\hline 5. & $\begin{array}{l}\text { Badan Pengembangan Sumber Daya } \\
\text { Manusia (BPSDM) Seragen }\end{array}$ & $\sqrt{ }$ & - & - & - \\
\hline 6. & $\begin{array}{l}\text { Pusat Kajian dan Pendidikan dan } \\
\text { Pelatihan Aparatur I LAN Jatinangor }\end{array}$ & $\sqrt{ }$ & - & - & - \\
\hline 7. & $\begin{array}{l}\text { Badan Pengembangan Sumber Daya } \\
\text { Manusia (BPSDM) Provinsi Riau }\end{array}$ & $\sqrt{ }$ & - & - & - \\
\hline 8. & 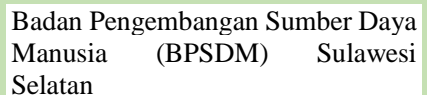 & $\sqrt{ }$ & - & - & - \\
\hline
\end{tabular}

\section{E. Penutup}

KPM memegang peranan penting dalam proses penyelenggaraan Diklat. Mengingat kesibukan penyelenggara Diklat, maka KPM dapat dimaksimalkan perannya. Evaluasi peran KPM terlihat dalam mem- bantu membuat standar baku penyelenggaraan Diklat, membuat instrumen evaluasi penyelenggaraan Diklat mulai dari tahap perencanaan sampai dengan evaluasi penyelenggaraan Diklat. Dalam membuat instrumen evaluasi penyelenggaraan dapat berupa instrumen penyelenggaraan (evaluasi 
terhadap penyelenggara dan pengajar), dan evaluasi pasca Diklat. Selain itu KPM harus dapat mengimplementasikan instrumen yang dibuatnya dalam setiap proses penyelenggaraan sehingga akan diperoleh catatan hasil penyelenggaraan Diklat. Jika memang ada yang belum sesuai, maka dapat dijadikan bahan perbaikan untuk penyelenggaraan selanjutnya. Lebih jauh, jika KPM dapat membuat instrumen pasca Diklat dan mengimplementasikannya, maka instansi penyelenggara Diklat memiliki data terkait dengan kualitas lulusan yang telah mengikuti Diklat pada instansi penyelenggara yang bersangkutan.

Sebagai tim yang menjalankan fungsi pengendalian dan penjaminan kualitas, maka KPM sebaiknya bekerja sesuai dengan tugas dan fungsinya sebagaimana yang tertuang dalam Peraturan Kepala LAN Nomor 25 tahun 2015 tentang Akreditasi Lembaga Diklat, lebih rinci dalam surat penugasan yang ditandatangani oleh Pimpinan Instansi Penyelenggara Diklat. Saat ini pembentukan KPM hanya sebatas untuk memenuhi syarat pengajuan akreditasi saja, tetapi peran dan fungsinya belum dilakukan secara maksimal. Untuk itu peran dan fungsi KPM harus diatur kembali kepada seluruh instansi Lembaga Diklat yang telah diakreditasi, agar apa yang menjadi tujuan Diklat dalam memenuhi kesenjangan kompetensi dapat terpetakan dengan baik. Pada akhirnya data kualitas lulusan Diklat dapat terpetakan dengan baik.

\section{Daftar Pustaka}

Djaali dan Pudji Muljono, 2008, Pengukuran Dalam Bidang Pendidikan, Jakarta: Grasindo

Sugiyono, 2009, Metode Penelitian Kuantitatif, Kualitatif dan $R \& D$, Bandung : Alfabeta

\section{$\underline{\text { Peraturan Perundangan }}$}

Peraturan Kepala Lembaga Administrasi Negara Nomor 25 tahun 2015 Pedoman
Akreditasi Lembaga Pendidikan dan Pelatihan Pemerintah. 20 April 2015. Berita Negara Republik Indonesa tahun 2015 Nomor 1114, Jakarta.

Peraturan Kepala Lembaga Administrasi Negara Nomor 21 tahun 2016 Pedoman Penyelenggaraan Pelatihan Dasar Calon Pegawai Negeri Sipil Golongan III. 23 November 2016. Berita Negara Republik Indonesia tahun 2016 Nomor 2065, Jakarta.

Peraturan Kepala Lembaga Administrasi Negara Nomor 22 tahun 2016 tentang Pedoman Penyelenggaraan Pelatihan Dasar Calon Pegawai Negeri Sipil Golongan I dan Golongan II. 23 November 2016. Berita Negara Republik Indonesia tahun 2016 Nomor 2066, Jakarta.

Peraturan Kepala Lembaga Administrasi Negara Nomor 20 tahun 2015 tentang Pedoman Penyelenggaraan Pelatihan Kepemimpinan Tingkat IV. 23 Maret 2015. Berita Negara Republik Indonesia Tahun 2015 Nomor 1223, Jakarta.

Peraturan Kepala Lembaga Administrasi Negara Nomor 19 tahun 2015 tentang Pedoman Penyelenggaraan Pelatihan Kepemimpinan Tingkat III. 23 Maret 2015. Berita Negara Republik Indonesia tahun 2015 Nomor 1222, Jakarta.

Peraturan Kepala Lembaga Administrasi Negara Nomor 18 tahun 2015 tentang Pedoman Penyelenggaraan Pelatihan Kepemimpinan Tingkat II. 23 Maret 2015. Berita Negara Republik Indonesia Tahun 2015 Nomor 1221, Jakarta.

Peraturan Kepala Lembaga Administrasi Negara Nomor 17 tahun 2015 tentang Pedoman Penyelenggaraan Pelatihan Kepemimpinan Tingkat I. 23 Maret 2015. Berita Negara Republik Indonesia tahun 2015 Nomor 1220, Jakarta.

$\underline{\text { Website }}$

Crosby, P.B, 1979, Quality is Free, http://www.philipcrosby.com, diakses tanggal 30 September 2017. 